Ujházi Lóránd ${ }^{1}$ - Horváth Tibor ${ }^{2}$

\title{
Szent László alakja a magyar haderőben. Gondolatok a fegyvernemi védőszentek kultikus tiszteletének alacsony fokáról ${ }^{3}$
}

DOI 10.17047/Hadtud.2020.30.E.123

\begin{abstract}
Absztrakt:
Minden év júliusában, Szent László király ünnepéhez kapcsolódóan emlékezik a Magyar Ejtőernyős Bajtársi Szövetség Szent László Hadosztály baráti köre Letkésen és a szlovákiai Ipolyszalkán azokra a magyar katonákra, akik a Második Világháború utolsó hónapjaiban a hadosztályban szolgáltak. László király a második világháborúig és a szovjet típusú bolsevik diktatúra magyarországi kiépítésig meghatározó példakép volt a magyar katonák számára a többi segítő vagy fegyvernemi védőszenttel való összehasonlításban is. Bár a rendszerváltás után Szent Lászlóra ismét mint a „övészek védőszentjére” tekintenek, de hatása messze elmarad a második világháborút megelőző időszaktól.

Ebben a tanulmányban arra keressük a választ, hogy mi az oka, hogy bár a jogszabályi környezet lehetővé tenné a komoly Szent László - és más fegyvernemi védőszent kultuszt a Magyar Honvédségben, az mégsem történt meg a rendszerváltás óta. Szeretnénk feltárni azokat a mélyebb történelmi és eszmetörténeti összefüggéseket, amelyek miatt a baloldali ideológia és annak szélsőséges bolsevik formája, de a liberális "demokrácia” ideológiája sem tud azonosulni Szent László - és a többi fegyvernemi védőszent - alakjával. A demokratikus jogalkotás elérte a maximumát azzal, hogy a kultusz- és vallásszabadságot engedélyezte a Magyar Honvédségben. Hipotézisünk szerint a kultusz életre keltéséhez olyan fordulatnak kellene bekövetkezni, amely a Francia Forradalom után folyamatosan elhatalmasodott szellemáramlatokkal kerülne szembe.
\end{abstract}

Kulcsszavak:

Szent László, ideológia, liberalizmus, fegyvernemi védőszentek

\footnotetext{
${ }^{1}$ Nemzeti Közszolgálati Egyetem Hadtudományi és Honvédtisztképző Kar - National University of Public Service, Faculty of Military Sciences and Officer Training; e-mail: ujhazi.lorand@uni-nke.hu; ORCID: 0000-0002-1630-8208

${ }^{2}$ Nemzeti Közszolgálati Egyetem Hadtudományi és Honvédtisztképző Kar - National University of Public Service, Faculty of Military Sciences and Officer Training; e-mail: horvathtibor@uni-nke.hu; ORCID: 0000-0003-4742-847X

${ }^{3}$ A tanulmány angol nyelvű változata megjelent: Hadtudományi Szemle, 13. évfolyam (2020), 1. szám, pp. 193-210.
} 


\title{
Cultic honours to Saint László (Saint Ladislaus) in the Hungarian Army. Thoughts on the Poor Cultic Honours to Branch Patron Saints
}

\begin{abstract}
:
Every July, in Letkés and Ipolyszalka (Slovakia) - relating to King St. László festivals -the Comrade Union of Hungarian Parachutists St. László Division commemorates Hungarian soldiers who served in the Division in the last months of WWII. The Division had nothing to do Waffen-SS nor with the armed corps of Hungarist Movement. It was a part of the Royal Hungarian Defence Forces, which still kept some tradition. King László, comparing to other supporter or branch patron saints, was a decisive hero to Hungarian soldiers until WWII and establishing the Soviet type bolshevik regime in Hungary. Although, after the change of political system, St. László was again considered to be 'the patron saint of riflemen', from time to time he is commemorated with Mass or a concert ${ }^{4}$, his influence remains far behind the period before WW II.

In this study we are trying get answers, why the cult of St. László's - and other branch patron saints - has not developed in the Hungarian Defence Forces since the change of political system, although the legislative environment makes it possible. We would like to reveal those deeper historical and the history of ideas correspondence that proves that not only leftist ideology, and its extreme Bolshevik form, but the ideology of liberal democracy cannot identify with St. László's - and other patron saints' - figure. We are pointing out that in the current ideological milieu there are insufficient grounds for the branch patron saints, besides ceremonial activities, to become awarenessraising power. To achieve this power, there should be a change, which would go against those ideas that gradually became overwhelming after the French Revolution. It is not judgement, but a hypothesis which is formulated so that we can reflect the phenomenon authentically. So do we formulate that democratic legislation has reached its maximum with allowing cult and religious freedom in the Hungarian Defence Forces. As numerous works have been written about St. László's life, his cultic honours, his role in tradition and arts, we touch upon his historic and art introduction, when it serves proving the assumption.
\end{abstract}

\section{Keywords:}

St. László, ideology, liberalism, branch patron saints

\section{Szent László történelmi alakjának tovább élése a keresztény eszme fényében}

Az abstractban említett Szent László hadosztály felállítását Csatay Lajos honvédelmi miniszter 1944. október 12-én a következő rendelettel hozta létre: „Hazánknak a keleti veszedelemmel: a szovjet bolsevizmussal vívott élet-halál harcában, a még rendelkezésünkre álló emberanyag legjavából egy új elithadosztályt, a Szent László

\footnotetext{
${ }^{4}$ Sárkány Beáta: Szent László előtt tisztelegtek a katonák. https://honvedelem.hu/cikk/57946 szent laszlo elott tisztelegtek a katonak (Downloaded: 09/07/2018)
} 
Hadosztályt állítom fel.. ${ }^{5} \mathrm{~A}$ honvédelmi miniszter azt sugallja, hogy a háború utolsó szakaszában létrehozott elitalakulatot mélyebb megfontolásból nevezték el Szent Lászlóról. Személyében, ahogy arra Magyar Zoltán monografikus munkájában felhívja a figyelmet, "megjelent magyar földön a civilizált harcos, a lovag”. ${ }^{6}$ Érthetö, hogy a civilizáció és a barbárság - értsd „keresztény Európa” és a bolsevizmus közötti harc szemléltetésére ilyen emblematikus történelmi alakot választottak. Személye érzékeltette, hogy az igazi háború a gonoszság és az igazság erői között történelemi távlatokban zajlik.

A háborúk szellemi dimenzióját szinte minden vallás elfogadja. Szent László kultikus tiszteletébe ezért kerülhettek be a honfoglalás elötti „pogány” hitvilág egyes elemei, amelyek más keleti nép hitvilágában is fellelhetők („elrabolt lány visszaszerzése, hősi birkózás, sebezhetetlen hősök küzdelme, táltosküzdelem, a lány szerepe a harc végkimenetelében, a mitikus ellenség, aki csakis egyetlen ponton, a lábinán sebezhető meg, vagy csak a saját fegyverével ölhető meg, a világfa, a nőrabló alvilági jellegű vonatkozásai, a táltos ló, illetve a ciklust lezáró pihenés jelenete, szerelmi együttlét, hősi álom). ${ }^{7}$ Ezek a történetek csak olyan társadalom számára tudatformálók, amelyek hisznek a természetfeletti erők létezésében, illetve hogy ezek az erök befolyásolhatják a háborúinkat. Mivel a szellemi létezőkbe vetett hit általánosan válságba került, nem meglepő, hogy Szent László kultikus tisztelete sem a magyar társadalomban, sem a haderőben nem meghatározó.

\section{Szent László történelmi és mitikus harcai a történetírásban és a legendáriumokban}

Szent László „életrajzát” - Vita - a kanonizáció alkalmával (III. Celesztin pápasága alatt, 1192-ben) ${ }^{8}$ két egymástól is eltérő „életírásból” állították össze. ${ }^{9}$ Gondolatvilága inkább a szentté avatást és az azt követő időszakot jellemezi. ${ }^{10} \mathrm{Az} 1192$ után keletkezett Kisebb Legenda - Legenda Sancti Ladislai regis minor - és a XIII. században keletkezett Nagyobb Legenda - Legenda Sancti Ladislai regis maior gyüjteményeket nem szabad a modern értelemben vett életrajzokhoz és történeti művekhez hasonlítani. Magyar Zoltán a Szent László-kultuszt elemző munkájában rámutat, hogy a szent egy személyben egyesíti a „korabeli férfieszményt”, az európai

\footnotetext{
${ }^{5}$ Történelmi háttér http://attilavedvonal.hu/tortenelmi-hatter/ (Letöltés ideje: 2018. 07. 09.)

${ }^{6}$ Magyar Zoltán: „Keresztény lovagoknak oszlopa”. Budapest, Nemzeti Tankönyvkiadó, 1996. p. 13.

${ }^{7}$ Magyar Zoltán: Szent László a magyar múvelödéstörténetben. Korunk, 2016. 8. szám, pp. 36-35. Az igazi törésvonal nem a kereszténység és a keleti hitvilág, hanem a természetfeletti létezőkben hívő és a nem hívő irányzatok között van.

${ }^{8}$ A szentté avatás dokumentációja kapcsán kialakult bizonytalansághoz lásd: Klaniczay Gábor: A Szent-László kultusz kialakulása. In: Uő (szerk): Nagyvárad és Bihar a korai középkorban. Nagyvárad, Varadinum Kulturális Alapítvány, 2014. pp. 18-19.

${ }^{9}$ Török József: Magyar szentek földjén. Budapest, Tulipán, 1999. p. 96.

${ }^{10}$ Nemeskürty István: Mi magyarok. Budapest, Dovin Múvészeti Kiadó kft., 1989. p. 56.
} 
lovag és uralkodó ideált, ${ }^{11}$ tisztelete egyedülállóan kapcsolódott össze az "egyházi szentkultusszal", illetve néphagyománnyal (...) és vált az Árpád-ház leginkább tisztelt uralkodójává. ${ }^{12}$ Ehhez társul a "teológiai” üzenet, hogy az uralkodó és a katona is lehet szent. ${ }^{13} \mathrm{~A}$ keresztény magyar király és vele a magyar nép pedig a jó oldalán részt vesz a princípiumok örök harcában. Ezeket a történeteket nem lehet a modern történetírás eszközével vizsgálni. De ez nem azt jelenti, hogy a "fantázia” világába kellene számüzni őket. Sőt, sokkal komolyabb kérdéseket vetnek fel, mint a puszta történeti elemzés: az emberiség helyére, a rossz és a jó, illetve a szellemvilág küzdelmeire és azon belül az egyes ember szerepére keresik a választ. ${ }^{14}$ Szent László országon átívelő tiszteletének kialakulásában szerepet játszott a formálódó szentté avatási eljárás. A Szentszék ugyanis fokozatosan magához vonta a szentté avatási eljárásokat. Ez nemcsak „eljárástechnikai” kérdés, hanem az egyház egyetemességének új területen való megjelenése, amely erősíti a „nemzeti” szentek országhatáron túli tiszteletét. ${ }^{15}$

László minden fórumon - a legendáriumokban vagy a művészetben - úgy jelenik meg, mint a jó princípium harcosa szemben a politikai vagy az országon kívülröl érkező katonai ellenségeivel, akik a gonosz földi reprezentánsai. Az imázs kialakításához nagyban hozzájárult László egyházhoz való viszonya. Komoly egyházszervező, az egyházat, beleértve a pápaságot is támogató tevékenységet fejtett ki. Ezt a Pápai Állam és a Magyar Királyság között a horvát trón magyar elfoglalásából (1091) adódó érdekellentét sem tudta beárnyékolni. Sőt, később ennek az eseménynek is megszületett az idealizált változata, amely a katonai akciót már úgy mutatta be, mint amelyet a keresztény erények vezéreltek, és amely az egyház érdekeit is szolgálta. ${ }^{16}$ Sőt László később igyekezett megnyeri II. Orbán (1088-1099) jóindulatát, hiszen horvát területen is templomokat és kolostorokat építtetett. Végül a helyzetet sem a pápa, sem a király nem élezte ki. ${ }^{17}$

István király, Imre herceg, Gellért püspök, András és Benedek remeték szentté avatásával László kulcsszerepet vállalt a magyar szentek tiszteletének megerősítésében. Megszülettek az új szentek „életrajzai”, liturgikus tiszteletük és ereklyéik őrzése. A magyar szentek - ahogy később maga László is - egyszerre

\footnotetext{
${ }^{11}$ Magyar Zoltán: Szent László a magyar művelődéstörténetben. i. m. p. 31. A szerző monografikus munkája még átfogóbb betekintést enged a népi és az egyházi kultusz kialakulásához és hatásaihoz. Magyar Zoltán: Szent László a magyar néphagyományban. Budapest, Osiris, 1998.

${ }_{12}^{12}$ Magyar Zoltán: Szent László a magyar müvelödéstörténetben. i. m. 30.

13 Bár Nemeskürty István úgy jellemzi Lászlót, mint aki inkább „hadvezér és hódító politikus”. Nemeskürty István: Mi magyarok. i. m. p. 51.

${ }^{14}$ Weisbender, Joseph: Szentek élete. Budapest, Szent István Társulat. 1984.

${ }^{15}$ Ujházi Lóránd: A csoda szerepe és jogi bizonyítása a boldoggá és a szentté avatási eljárásokban. In: Nagypál Szabolcs, Bányai Ferenc, Bakos Gergely (szerk.). A vallási tapasztalat megértése: Jog, bölcselet, teológia. Budapest, Pannonhalma, L'Harmattan Kiadó; Békés Gellért Ökumenikus Intézet, 2010. pp. 169-198.

16 Bánlaky József: Horvátország meghódítása 1091-ben. In: Uő (szerk) A Magyar nemzet hadtörténelme. Digitális kiadás: Arcanum Adatbázis Kft., 2001. http://mek.oszk.hu/09400/09477/html/0004/199.html (Letöltés ideje: 2018. 07. 18.).

${ }^{17}$ Magyar Zoltán: „Keresztény lovagoknak oszlopa”. i. m. p. 26.
} 
válnak a „nemzeti” összetartozás és az egyetemes egyházhoz tartozás jelképévé. ${ }^{18}$ A szentek kultusza kapcsán Nemeskürty István különösen a „szentistváni hagyomány" megerősítésére hívja fel a figyelmet. ${ }^{19}$ Magyar Zoltán pedig hozzáfüzi, hogy László „uralkodói nagyságát és intellektusát különösen” is mutatja, hogy a „nagyapját megvakító Istvánt kanonizálja." ${ }^{20}$ Ehhez az a józan belátás is hozzájárult, hogy István szellemi, lelki örökségével szemben László nem számíthatott volna stabil bázisra és hosszas uralkodásra. Klaniczay Gábor is utal arra, hogy a királykultuszok kialakítására leginkább Lászlónak volt szüksége az uralom megszilárdításához. ${ }^{21}$

A Zágrábi Püspökség alapítása, a nagyváradi, a váci, a gyulafehérvári székesegyház építtetése, ${ }^{22}$ az egyházi ünnepek számának növelése, az egyházmegyék határainak pontosítása, az egyháznak tett jelentős birtokadományok, az apátságok és kolostorok alapítása szintén jelentős egyházpolitikai lépésnek számított. Ehhez járult még, hogy az egyház helyzetének megszilárdítására összehívta az 1092-es szabolcsi zsinatot, valamint, hogy a kutaknál, fáknál történő áldozatokat szigorúan büntették. Györffy György megjegyzi, a papság benne látta az egyház második magyarországi alapítóját. ${ }^{23} \mathrm{~A}$ kutatók nem hagynak kétséget afelől, hogy a latin egyházat támogató uralkodói intézkedések nem nélkülözték a politikai szempontokat, hiszen Lászlónak szüksége volt az egyre befolyásosabb egyház támogatására. ${ }^{24}$ Bollók János még hozzáteszi, hogy a pogány szokások léte állandó fenyegetést jelentett, mivel az európai keresztény uralkodók a kereszténység védelmére hivatkozva feljogosítva érezték magukat Magyarország belügyeibe való beavatkozásra. ${ }^{25}$ Mindez persze teljesen érdektelen abból a szempontból, hogy László jelentősen hozzájárult annak az értékrendnek az erősítéséhez, amely a Francia Forradalomtól és az azt követő szellemi irányzatoktól, illetve az arra épülő állam- és társadalmi berendezkedéstől idegen.

\section{A pápaság és a császárság harcának hatása a kultusz kialakulására}

László nemcsak zavaros körülmények, trónviszályok és lázadások között erősíti meg a magyar államiságot, hanem részese a „császárság” és a pápaság egyik első

\footnotetext{
${ }^{18}$ Ez a „nemzeti” vonal a későbbiekben egyre erősebb lesz. Ahogy Ignácz Rózsa fogalmaz „(...) hosszú alvás után a nemzeti újra ébredés korában (...) nem az egyház szentje támad fel (...). A nemzeti történelem alapját képező krónikák Lászlóját a humanista reneszánsz Lászlóval ötvözötten élik meg újra a nemzeti újra ébredők”. Ignácz Rózsa: Ünnepi férfiú. Budapest, Fapadoskönyvek, 1989. p. 89.

${ }_{19}$ Nemeskürty István: Mi magyarok. i. m. p. 52.

${ }^{20}$ Magyar Zoltán: „Keresztény lovagoknak oszlopa”. i. m. p. 14.

${ }^{21}$ Klaniczay Gábor: A Szent-László kultusz kialakulása. i. m. p. 9.

22 Puskely Mária Claudia: Magyar szentek: Szent István, Szent Imre, Szent Gellért, Szent László, Szent Erzsébet, Szent Margit. In: Magyar kereszténység ezer éve. Budapest, MKPK, 2001. p. 152.

${ }_{23}$ Györffy György: Szent László. In. Kurucz Ágnes (Szerk.): László király emlékezete. Budapest: Magyar Helikon, 1977. p. 18.

${ }^{24}$ Koszta László erre a tényre már László elötti évek kapcsán, illetve általánosságban több alkalommal is felhívja a figyelmet. Koszta László: Válság és megerősödés: Pogánylázadások és konszolidáció (1038-1196). Budapest, Kossuth Kiadó, 2004.

${ }^{25}$ Bollók János: Szent László korának magyar értelmisége. Vigilia, 65. évf. (2000), 11. szám, p. 842.
} 
nagyformátumú harcának. VII. Gergely (1073-1085) és IV. Henrik (1056-1106) német-római császár „elkeseredett” küzdelme, amely „invesztitúra-harc” néven vonult be a történelembe, nemcsak az egyházi hivatalok betöltéséröl szólt, hanem az „állam és egyház" egymáshoz való viszonyának mélyebb kérdéseit vetítette elöre. Tattay Szilárd árnyaltan fogalmaz, amikor körbejárja a császárság, mint politikai hatalom és az egyház, mint lelki-szellemi „kiválóság” viszonyát. Tattay ugyanis más szerzőkkel ellentétben nem a császárság és a pápaság harcáról, hanem a „regnum (impérium) és a sacerdotium viszonyáról" ír. ${ }^{26} \mathrm{~A}$ két entitás egymáshoz való kapcsolata ugyanis nem szükíthető le csak a „harcra”, még ha a marxista történetírás szerette is ez utóbbi szempontra helyezni a hangsúlyt. Tattay értekezéséböl az is kiderül, hogy az „egyház-állam” kapcsolatát összetettebb filozófiai és teológiai kérdések határozták meg, mintsem csak az „egyházi hivatalok betöltése”. ${ }^{27}$ A magyar László király és a pápaság, illetve László és VII. Gergely, majd II. Orbán pápa viszonya ambivalens volt. Azonban ez esetben sem a történelmi tények pro és kontra értékelése témánk szempontjából a fontos, hanem a történetek későbbi lecsapódása, amely hozzájárult annak a képnek az erősítéséhez, hogy László a kereszténység és az egyház védelmezőjeként jelent meg. A Pápai Állam és konkrétan VII. Gergely politikai igényét, amellyel a Magyar Királyság feletti politikai hatalom kiterjesztésére törekedett, annak előzményeivel együtt Bollók János tanulmánya dolgozza fel. ${ }^{28} \mathrm{~A}$ szerző nem hagy kétséget afelöl, hogy VII. Gergely - éppúgy, mint elődei - részéröl volt igény a pápai hübéri jogok megerősítésére. A Magyar Királyság a császárság és pápaság között örlődött. László azonban ügyesen használta fel a külpolitikai helyzetet saját pozíciójának a megerősítéséhez. ${ }^{29} \mathrm{~A}$ VII. Gergely által bevezetett reformok kapcsán a kutatók sok esetben túlhangsúlyozzák Gelasius pápa Anastasius császárhoz 494-ben írt levelét. A levél való igaz, hogy a világi hatalom és az egyház, mint lelki „kiválóság” egymáshoz való kiegyensúlyozott viszonyának kialakítását tűzte ki célul, de egyáltalán nem tagadja az egyház elsőbbségét, tekintve annak természetfeletti küldetését. Továbbá az ötödik századi pápai levél elött is bőven voltak olyan teoretikusok - Szent Ambrus vagy Szent Ágoston -, akik behatóan foglalkoztak az „államhatalom” és az egyház viszonyával. Szinte egyikük sem hagyott kétséget az egyházi hatalom elsőbbsége felöl, abból az egyszerü okból kiindulva, hogy az egyház küldetése a természetfeletti salus animarum, a lelkek üdvösségre vezetéséhez kapcsolódik. ${ }^{30}$ De a gelasiusi szöveg is azt sugallja, hogy

\footnotetext{
${ }^{26}$ Tattay Szilárd: Regnum és sacerdotium. In: Takács Péter (szerk.): Államelmét. A modern állam elméletének előzményei és történeti alapvonalai. Budapest, Szent István Társulat, 2009. p. 59.

27 „Duo quippe sunt, imperator auguste, quibus principaliter mundus hic regitur, auctoritas sacra pontificum et regalis potestas." Epistolae pontificum romanorum genuinae. In: Andreas, Theil: Brunsbergae, Peter Signatur. 1868. p. 35.

${ }^{28}$ Bollók János: Szent László korának magyar értelmisége. i. m. pp. 841--849.

${ }^{29}$ A konszolidáció szempontjából lásd még Makk Ferenc: Megjegyzések a Szent László korabeli magyar-bizánci kapcsolatok történetéhez. Acta Universitatis Szegediensis Sectio Historica (19571959), 96. évf. (1992). pp. 13-24.

${ }^{30}$ Erröl ad átfogó képet Atkins, Margaret, Dodaro, Robert: Augustine Political Writings. Cambridge, University Press, 2004.
} 
az egyház bizonyos értelemben éppen a lelki hatalom birtoklása miatt elörébb való, mint az állam. ${ }^{31} A z$ Sz. Jónás llona szerkesztésében megjelent középkori-egyetemes történeti szöveggyüjtemény kérdéshez összegyüjtött forrásaiból is kiderül: ha nem is olyan kiélezett formában, mint VII. Gergely és IV. Henrik időszakában, de az államegyház „egymáshoz való viszonyának” értelmezésében a gelasiusi levél megírása és a VII. Gergely közötti időszakban is voltak egyenletlenségek. ${ }^{32}$

VII. Gergely „alapvetően” nem módosította Gelasius állam-egyház felfogását, hiszen a dolog természete és az ember végső céljáról vallott teológiai felfogás mindig is a lelki hatalom és a lelki hatalommal rendelkező entitás elsöbbségét vallotta. Amennyiben az egyház úgy ítélte meg, hogy a világi hatalom veszélyezteti a legfőbb értéket, mozgásterének megfelelően közbeavatkozott. VII. Gergelyt 1073. április 22én választották pápává, és rá egy évre tiltotta el a szolgálattól a nős és a simóniás papokat, majd 1075-ben arról rendelkezett, hogy a laikusoknak ne adományozhassanak egyházi hivatalokat, illetve megtiltotta, hogy a császár az invesztitúrát gyakorolja. Az 1056 óta uralkodó IV. Henrik már jóval VII. Gergely megválasztása előtt saját embereivel töltötte fel az egyházi hivatalokat. Sőt a pápai rendelkezések után a kölni és a milánói érseket régi szokása szerint nevezte ki. A wormsi birodalmi gyűlésen pedig a német „püspökök”, akiknek kinevezése nyilván az említett több évtizedes császári gyakorlat szerint történt, "letették" VII. Gergelyt. Az ismert Canossa-járás ellenére 1081-ben IV. Henrik ostrom alá vette Rómát, és III. Kelemen személyében ellenpápát állított, VII. Gergely pedig számkivetettségben halt meg. ${ }^{33}$ Személyükben az egyház és az „állam” kapcsolata új fordulatot vett, amely az államiságát megszilárdító Magyar Királyságra is kihatással volt.

Szent László VII. Gergely melletti elköteleződésében a politikai szempontok is szerepet játszottak. László 1079-ben vette feleségül Rheinfeldi Rudolf, IV. Henrikkel

\footnotetext{
31 „Dicsőséges császár, két olyan intézmény van, amely elsősorban kormányozza ezt a világot: az egyik a legfőbb papok megszentelt tekintélye, a másik pedig a királyi hatalom. A papok viselte teher annyiban nehezebb, amennyiben az Isten itélöszéke elött az embereken uralkodó királyokért is nekik kell számot adniuk. (Kiemelés - U. L.) Hiszen jól tudod magad is, te legjámborabb fiunk, hogy ha az emberi nembeliek elött jársz is méltóságoddal, azok elött, akik az Isten dolgaiban elöljárók, magad is alázatosan meghajtod a fejedet, s te is tölük várod saját üdvözülésed útját-módját, s az égi eredetü szentségek felvétele tekintetében, $s$ azok illendőképpen való kiosztásában a vallás rendje szerint el kell ismerned azt, hogy neked kell magadat alájuk rendelned, s nem te állsz az ő élükön; egyszóval: ezekben a dolgokban te függsz az ő ítéletüktöl, s nincs is szándékodban az, hogy te rendeld őket a saját akaratod alá. Ha pedig - már ami a közrendet illeti - az egyházi elöljárók, tudván azt, hogy hatalmadat felső rendelésből kaptad, törvényeidnek maguk is engedelmeskednek, annak érdekében, hogy még a világi dolgokban se támadjanak külön vélemények, akkor tehát - azt kérdem töled milyen odaadással kell azoknak engedelmeskedni, akik a mindenekfelett tiszteletre méltó misztériumokkal vannak felruházva? - És ha illendő dolog az, hogy a hívek általában véve valamennyi olyan papnak, aki a szent dolgokkal igaz módon törődik, alárendeljék szívüket, mennyivel inkább egyet kell érteni a legföbb papi széknek azzal a betöltőjével, akikröl úgy rendelte a legfelsőbb isteni akarat is, hogy valamennyi pap élén álljon, de ezt az akaratot követve, az egyetemes egyház áhítata is mindenkor ezzel a tisztelettel övezte."

${ }^{32}$ Sz. Jónás llona (szerk.): Középkori egyetemes történeti szöveggyüjtemény. Budapest, Osiris, 1999.

33 Tarján M Tamás: 1077. január 28. | Véget ér Henrik császár Canossa-járása. Rubicon. http://www.rubicon.hu/magyar/oldalak/1077 januar 28 veget er henrik csaszar canossa jarasa/
} (Letöltés ideje: 2018. 07. 09.). 
szembenálló német ellenkirály Adelhaid nevű leányát. (Ebből a házasságából született, Piroska leánya, aki a görög császár felesége és a bizánci egyház szentje lett). László döntése azonban bármennyire is politikai volt, hozzájárult a későbbi egyházias megítéléshez és a kultuszához. ${ }^{34}$ Hozzájárult ahhoz a képhez, hogy ő az igaz ügy, az egyház védelmezője, szemben Salamon királlyal. Ez utóbbi, legalábbis a későbbi interpretációkban úgy jelent meg, mint aki nemcsak László, hanem a magyar „szuverenitás” ellensége is, hiszen felajánlotta hübérül Magyarországot a császárnak, amennyiben az támogatja őt a Lászlóval szembeni harcban. Még a László-kultuszt feldolgozó tizenkilencedik századi elbeszélésekben is, mint Karácson Imre László halálának nyolcszázadik évfordulója alkalmával kiadott monográfiájában is központi helyet foglal el László pápa iránti elköteleződése. ${ }^{35}$

A László-kultusz szempontjából ez azért jelentős, mert amíg VII. Gergely az egyház - majd később átvitt értelemben a kereszténység, illetve a keresztény értékrend - védelmezőinek, addig IV. Henrik az egyházat elnyomó erőknek az emblematikus alakjává vált. A két entitás közötti viszonyt jól jellemezi, hogy ebben az időben az egyház részéről még az is megkérdőjeleződik, hogy a király hivatala harcolnia kell, vezeti a népet a csatában, kemény, adott esetben halálos ítéletet is hoz -, nem összeegyeztethető a keresztény szent ókeresztény ideájával. ${ }^{36}$ Lászlónál azonban éppen a formálódó keresztény királyeszme szempontjából igazolták uralkodói alkalmasságát (idoneitását). Nem a legalitásra helyezték a hangsúlyt, amely a történészek meggyőződése szerint Salamonnal, a törvényes királlyal szemben nem is állta volna ki a próbát. ${ }^{37}$

Szent László az egyházat védő lovagkirály eszméje szemben áll azokkal az irányzatokkal, amelyek az egyházat és a kereszténységet nem védendő, hanem megsemmisítendő vagy „semleges” formációnak tekintik. László „csatlakozik” azokhoz a szentekhez, akiknek tisztelete túlmutat saját „országuk” határain, ${ }^{38}$ hiszen ők már annak az univerzalizmusnak és értékrendnek a védelmezői, amelyet az egész egyetemes anyaszentegyház képvisel, és amelyekkel a későbbi

\footnotetext{
${ }^{34}$ Elég VIII. Bonifác és Szép Fülöp konfliktusára gondolni, amelyet előszeretettel értelmeztek az egyházzal szemben. Már közvetlenül a pápa halála után az egyházi íróknak védelmükbe kellett venniük a pápai rendelkezést, és magyarázni kellett annak az igazi okát. Ehhez lásd Szovák Kornél: Potestas papae potestas regia. Politikai viták a 14. század elején. Vigília, 64. évf. (1999), 2. szám. pp. 93-99.

${ }^{35}$ Karácson Imre: Szent László Király Élete. A Győri Szent-László-Társulat Megbizásából. A Szent Király Halálának Nyolczszázados Évfordulójára. Győr, Győregyházmegye Könyvnyomdája, 1895.

${ }^{36}$ Klaniczay Gábor: A Szent-László kultusz kialakulása. In: Uő (szerk.): Nagyvárad és Bihar a korai középkorban Nagyvárad, Varadinum Kulturális Alapítvány, 2014. p. 9.

${ }^{37}$ Bollók János: Szent László korának magyar értelmisége. i. m. 848.

${ }^{38}$ A magyar királyok liturgikus és hagiográfikus tiszteletének Magyarországon túlívelő vetületére hívja fel a figyelmet Madas Edit irodalomtörténész. Madas Edit: A magyar „szent királyok” közép-európai kultusza liturgikus és hagiográfiai tisztelete a források tükrében. http://real.mtak.hu/9736/1/AH 201312 Madas Edit.pdf (Letöltés ideje: 2018. 07. 08.). Lásd még: Madas Edit - Horváth Zoltán György: Középkori prédikációk és falképek Szent László királyról. San Ladislao d'Ungheria nella predicazione e nei dipinti murali. Budapest, Romanika Kiadó, 2008. p. 464.
} 
egyházellenes törekvések - a baloldaliság és a liberalizmus - szembekerültek. ${ }^{39} \mathrm{~A}$ katonaszent tisztelete így elválaszthatatlanná válik az egyház tanításától és értékrendjétöl, amely pedig egyetemes és nemzetek feletti. ${ }^{40}$

\section{Szent László tisztelete a történelmi események és legendák fényében}

László lovagkirályi kultuszát későbbiekben erösítette, ${ }^{41}$ hogy Nagy Lajos (13421382) magára is mint "lovagkirályra”, Lászlóra pedig mint példaképére tekintett. ${ }^{42}$ Egyes vélemények szerint László lovagideál képének kialakulásához az is hozzájárult, hogy Magyarországon a valóságban a nyugati értelemben vett lovagság soha nem alakult ki. Így legalább az ideákon keresztül szerettek volna kapcsolódni a lovageszmékhez. ${ }^{43}$ A Szent László-kutatás szakértői vitatják, hogy a természetfeletti elemeket tartalmazó történetek pontosan mikor keletkeztek. Az általunk tárgyalt eszmetörténeti hatás szempontjából ez a kérdés irreleváns. ${ }^{44} \mathrm{~A}$ természetfeletti erök közbeavatkozása már a Salamon és László közötti viszályban megjelenik. A „csodafiúszarvas" látomásával egybekötött váci egyházalapítás angyali jelenéshez kapcsolódik. A mogyoródi csata előtt László látomásban látja, hogy az angyalok leszállnak az égből és Géza fejére koronát helyeznek, mintegy megjövendölve a csata kimenetelét. ${ }^{45}$ A mogyoródi győztes csata után pedig (1074. március 14.) László égi segítséget kap, hogy elfoglalja Salamon pozsonyi állását. ${ }^{46}$ „Tudjátok meg, emberek elöl nem menekültem volna el, de ez nem ember, hanem tüzes karddal védelmezik őt az angyalok." Vallja be Salamon az udvartartásának a pozsonyi ütközet után, amelyről a legendárium úgy számol be, hogy „László feje

\footnotetext{
${ }^{39}$ Erről átfogó képet fest szinte minden politológiai bevezető munka. Nem hagynak kétséget a modern demokrácia és a „liberalizmus” különböző formái közötti kapcsolatról. Mándi Tibor - Körösényi András: A magyar politikai rendszer egy negyedszázad után. Budapest, Osiris, 2015. pp. 13-32.

${ }^{40}$ Erre a tényre már a háború előtti szerzők is rámutattak. Guoth Kálmán: Eszmény és valóság Árpádkori királylegendáinkban. Erdélyi Tudományos Füzetek, 187. Kolozsvár. 1944.

${ }^{41}$ Harai Dénes bemutatja hogyan él tovább Szent László alakja az archaikus népi gondolkodásban. Harai Dénes: Az archaikus népi gondolkodás. Kaposvár, Kató Zsolt, 2016.

42 János István: „Légy a hazádnak bajnoka.” Szent László alakja a magyar irodalomban. SzabolcsSzatmár-Beregi Szemle, 1992. p. 139.

${ }^{43}$ Veszprémy László - Szabó Péter: Szent László a gyalogság védőszentje. Budapest, Magyar Honvédség, Oktatási és Kulturális Anyagellátó Központ, 1993. p. 19. A lovageszme és nyugati behatásokhoz lásd a szerző másik munkáját: Veszprémy László: Magyar király a Szentföldön: II. András keresztes hadjárata, 1217-1218. Figyelő, 31. évf. (2009), 4. szám, pp. 3-9.

${ }^{44}$ Egyes elméletekhez lásd: Klaniczay Gábor: A Szent-László kultusz kialakulása. i. m. p. 13.

${ }^{45}$ Váczy Péter: Az angyal hozta korona. Életünk, 19. évf. (1982), 1-2. szám, pp. 456-466.

46 Salamon bukása. I. Géza király. https://www.arcanum.hu/hu/onlinekiadvanyok/MagyarNemzetTortenete-a-magyar-nemzet-tortenete-9A23/szilagyi-sandor-a-magyarnemzet-tortenete-21F2/magyarorszag-tortenete-az-arpadok-koraban-10381301-2B1F/elso-konyvkuzdelem-a-nemzeti-fuggetlensegert-2B32/v-fejezet-salamon-bukasa-i-geza-kiraly-2C42/ (Letöltés ideje: 2018. 07. 11.); Veszprémy László - Szabó Péter: Szent László a gyalogság védőszentje. i. m. p. 13. - Egyéb „csodás” eseményeket is tartalmaz a krónika, minthogy László lelki szemével már elöre látta a győzelmet, amely „királlyá teszi Gézát”, illetve az ütközet előtt a megrázott bokorból egy menyét szaladt fel László lándzsáján.
} 
fölött (az angyalok) tüzes karddal repkedtek és a herceg ellenségeit fenyegették." 47 Az angyalok, mint Isten „serege” mind az Ószövetségben (Ter 32 1-2; Jozs 5, 1314), mind az ószövetségi apokrif irodalomban (1Hén 61,10; 71,7), mind az Újszövetségben (Jn 1,47-51) ${ }^{48}$ mint pozitív erők jelennek meg. Az angyalok, mint Isten harcosai az apokaliptikus irodalomban különösen nagy hangsúlyt kapnak, hiszen maga az „apokaliptikus müfaj” az utolsó idők, a fény és a sötétség, a gonoszság és az igazság utolsó nagy ütközetét tárják elénk, amelyben a természetfeletti erők jelentős szerepet játszanak. ${ }^{49} \mathrm{Az}$ angyalok, mint az igazakat segítő erők tovább éltek az első századi keresztény szerzők teológiai, de mai szóval „társadalomelméleti” munkáiban is. ${ }^{50}$ László harca a kunokkal a kerlés-hegyi csatában hasonló jelképvilággal rendelkezik. A történet ez esetben is túlmutat a két hadsereg harcán: A király győzelme pedig a kereszténység pogányság feletti diadalát jelképezi. ${ }^{51}$ Természetesen ez esetben sincs egyetértés sem a történet eredete, sem a keletkezési időszak tekintetében, de a történet lényegi üzenete szempontjából: a természetfeletti erők örök harca szempontjából ennek nincs is jelentősége.

A természetfeletti közbeavatkozás elemeit tartalmazza a Szent László kútjához kapcsolódó legenda is. A Lengyel Dénes által összegyűjtött mondagyűjteményben Régi magyar mondák címmel rögzített elbeszélés szerint Szent László király uralkodása alatt az „oroszok betörtek Magyarországra, sok falut, várost feldúltak, aztán a sok zsákmánnyal hazaindultak." A király sereggel utánuk indult, de elesége elfogyott, és a kietlen pusztaságban nem találtak élelmet. László „csendesen elvonult, térdre esett, úgy könyörgött az Úristenhez. Én uram-teremtőm, amiképpen régen Izrael népét a pusztában mennyei kenyérrel megelégítetted, aképpen a

\footnotetext{
${ }^{47}$ Thuróczy János: A Magyarok Krónikája. Augsburg. 1486. (Ford. Horváth János) Budapest, 1918. p. 187. Elérhető: http://nemzeti.net/contents/library/01-MAGYARKR.pdf (Letöltés ideje: 2018. 07. 11.)

${ }^{48}$ „Bizony, bizony, mondom nektek: látni fogjátok, hogy megnyílik az ég, és Isten angyalai fel-alá szállnak az Emberfia felett." (Jn 1,51)

${ }^{49}$ Hartman, F. Louis - Lella, A. Alexander: Daniel. In: Brown, E. Raymond, Fitzmayer, A. Joshep, Murphy E. Roland (szerk.): The New Jerome Biblical Commentary. Burns and Oates, New Jersy. 1990. pp. 406-420.; Bauckham, Richard: Revelation. In: Barton, John, Muddiman, John (szerk.): The Oxford Bible Commentary. Oxford, University Press, 2001. pp. 1287-1316.

50 Számos korai keresztény szerző mélyen foglalkozott a jó és a rossz természetfeletti harcának gondolatával. Babcock, S. William: Angels. In: Everett Ferguson (szerk.): Encyclopedia of Early Christianity. New York-London, Garland Publishing, 1998. pp. 54-55.

${ }^{51}$ A Képes Krónika így írja le: Meglátott végül Szent László herceg egy pogányt, aki egy szép magyar lányt vitt lova hátán, Szent László herceg pedig úgy gondolván, hogy az a váradi püspök lánya, s noha súlyosan meg volt sebesülve, tüstént üldözni kezdte lovával, melyet Szögnek nevezett. Amikor pedig már elérte volna őt, hogy lándzsájával ledöfje, semmiképpen sem volt erre képes, mivel sem az ö lova nem futott gyorsabban, sem amannak a lova nem maradt le semennyire sem, hanem mindegyre kartávolság volt a lándzsa és a kun háta között. Így kiáltott és szólt Szent László herceg a lányhoz: „Szép húgom, ragadd meg a kunt az övénél és vessed magad a földre!” Meg is tette ezt. Amidőn pedig Szent László herceg a földön fekvőt közelről lándzsával ledöfte volna, ugyanis meg akarta öt ölni, a lány nagyon kérte, hogy ne ölje meg azt, hanem engedje el. Ebböl is látszik, hogy nincs hüség az asszonyokban, mivel fajtalan szerelemből kívánta őt megszabadítani. A szent herceg pedig sokáig viaskodott vele, s miután inát elvágta, megölte őt. De az a lány nem a püspök lánya volt." Budapest, Szépirodalmi Könyvkiadó, 1984. pp. 239-242. (Ford: Bollók János.)
} 
szegény keresztény népet se engedd éhen meghalni!" Az imádság után szarvasok, őz, meg bivaly vonult szeme előtt a tábor felé. (...)." ${ }^{52}$ A történetben fel lehet fedezni más „szent királyok” elbeszéléseit, ${ }^{53}$ illetve az ószövetségi nép pusztai vándorlását. A pusztai vándorlás a manna történettel egyszerre az isteni gondoskodás-, de emellett a különböző „kánaánita népekkel” való harcok elbeszélése. Az ószövetségi üzenet lényege is az volt, hogy a „végső győzelmet” nem elsősorban a nép, hanem a könyörülő Isten természetfeletti segítsége adja. ${ }^{54} \mathrm{~A}$ modern vallástörténeti kutatás is alátámasztja, hogy a közel-keleti „jahvizmus” a többi kánaánita valláshoz képest egyedülálló volt, amelyet a radikális igaz-hamis, jó és rossz szembeállítással hangsúlyoztak. $^{55} \mathrm{Ez}$ az elem pedig a keresztény szentkultuszban - jelen esetben a Szent László kultuszban - is tovább élt.

Szintén az ószövetségi kivonulással „paralel” történetként is értelmezhető, mikor szomjúság kínozza Szent László katonáit, akik a tatárok ellen vonulnak. Mielőtt ütközetre került a sor, László Istenhez fohászkodott, aki meghallgatta a könyörgését, és László lova patkójának nyomán bőséges forrás fakadt. Eltekintve a történet valóságtartalmától, eszmetörténeti szempontból jelentős az elbeszélés, mivel Szent László úgy jelenik meg, mint Mózes, aki vizet fakaszt a sziklából és felkészíti a választott népet a kánaánitákkal való harcra. De párhuzamokat az európai "lovagkirályok" legendáriumában is találunk. A történetiség mögötti üzenet a lényeges: az Isten választottjai és az istentelen népek örök harcban állnak, illetve, hogy a jó és rossz harcában Isten a választottakat segíti.

Szent László halála után is természetfeletti erővel védelmezi a harcban azokat, akik a jó princípiumok mellett kötelezték el magukat. ${ }^{56}$ Szép példa erre a valós történelmi eseményt legendás elemekkel kiegészítő elbeszélés, amikor „Szent László király megjelenik az 1345-ös moldvai ütközetben." Az elbeszélés történelmi magja, hogy Nagy Lajos király Lackfi Endrét, a későbbi erdélyi vajdát székely seregekkel a tatárok földjére küldte, mivel a tatár betörések fenyegették a Magyar Királyság biztonságát. A székelyek a Dnyeszter innenső oldalán megütköztek és a három napos csatában a többszörös túlerővel szemben sikerült győzniük. Szent László „ideologizált" tovább élése szempontjából azonban jelentősebb az a legenda, amelyet a Budai krónika ${ }^{57}$ és Pór János minorita krónikatöredéke is megörzött. ${ }^{58}$

\footnotetext{
${ }^{52}$ Lengyel Dénes: Régi magyar mondák. Budapest, Móra Ferenc Könyvkiadó, 1972. p. 155.

${ }^{53}$ Horváth Cyrill: Szent László-legendáink eredetéröl. Budapest, 1928. pp. 17-19.

54 Thomas, Charles, Léon-Dufour Xavier: Puszta. Léon-Dufour Xavier (szerk.): Biblikus teológiai szótár. Budapest, Szent István Társulat, 1972. p. 1124.

${ }^{55}$ Ehhez átfogó monográfia a különböző elméletek feldolgozásával: Rózsa Huba: Az ószövetség keletkezése. Budapest, Szent István Társulat, 1986.

${ }_{57}^{56}$ Magyar Zoltán: „Keresztény lovagoknak oszlopa”. i. m. p. 13.

57 „A csuda megtörténtéröl a foglyok is tanúságot vallottak. Egy vén tatár mondá, hogy nem a székelyek, meg a magyarok, hanem ama László, kit mindig segítségül szólítanak, verte meg őket. Más foglyok pedig ezt beszélték: »Mikor a székelyek ellenük jövének, élükön szálas vitéz nagy lovon ülve, fején arany koronával, kezében szekercés lándzsával (dolabrum), borzasztó suhintásokkal és csapásokkal rontott meg bennünket. E vitéz feje fölött pedig egy gyönyörüséges úri asszony, szintén koronás fővel, ékes és fényes ruhában lebegett. « Világos, magyarázza a krónikás, hogy a Krisztus
} 
Amikor már minden elveszettnek tűnt, csodálatos jelenés tűnt fel az égen, és a lovagkirály visszatért, hogy segítsen a bajban lévő katonáknak. Ehhez társult még a hiedelem, hogy a szent fejereklyéje a harcok idejére eltűnt a székesegyházból, és csak a harmadik nap került elő „átizzadva” a csatában.” ${ }^{9}$ A történetnek annyi valóságtartalma lehetett, hogy a „harcos lovagkirály, a katonaszent” ereklyéjét, ahogy arra más európai katonaszentek, mint például Szent Márton esetében is találunk utalást, elöre vitték a csatába, hogy az ereklye természetfeletti segítséget adjon. A tatárokkal szembeni harc itt sem csak „két fegyveres erő” ütközete: a kereszténység mint világosság és a „pogányság”, mint a sötétség erői csapnak össze. Más európai keresztény népek körében sem volt ismeretlen, hogy hazájuk biztonságát valamelyik „katonaszenttel” összekapcsolták. Ez történt III. Edvárd angol király (1327-1377) idején, amikor Szent György kezébe vagy Észak-Hispániában, ahol Szent Jakab védelmébe ajánlották az országot. Utóbbi Lászlóhoz hasonlóan „megjelent” a mórok elleni 844-es clavijói csatában. ${ }^{60}$ De hasonló történetről számolnak be Szent II. Olaf (1016-1030) esetében is. Párhuzamos történeteket a bizánci katonaszentek - Szent György, Dömötör és Teodor - legendái is tartalmaznak. ${ }^{61}$ Különösen a Szent Dömötörről szóló elbeszélés mutat hasonlóságokat a Szent László legendákkal, mikor Dömötör „az oltalma alatt álló várost személyesen, fehér lován ülve, mennyei sereg élén megvédi az ellenség támadásaitól." ${ }^{2}$

Nincs egyetértés a kutatók között, hogy az említett Szent László-legendák és kultusz kialakulásában milyen hatása volt a bizánci legendáriumoknak, de a mi szempontunkból ez nem is jelentős. ${ }^{63}$ Ezeknek a történeteknek a lényege ugyanis, hogy vannak közös, népeken, határokon átívelő elemei a katonaszentek tiszteletének, amelyek a kereszténység által képviselt értékeket és univerzalizmust erősítik. A keresztény legendák közös elemei nemcsak az adott szenteket, hanem a szenteket tisztelő népeket is egy közös hitvilágba kapcsolja össze, amelynek szerves része a jó és a gonosz harca és az ember természetfeletti célja. Olyan tanítás és

hitéért harcoló székelyeket maga a Szent Szűz és Szent László segítette a saját erejökben és sokaságukban elbizakodott tatárok ellen." (Budai Krónika)

${ }^{58}$ „A három napra - így szól a legenda -, míg e harc tartott, Szent László feje a váradi templomból, ahol örizték, eltűnt. Midőn pedig a kincsőrző kanonok negyednapon a maga helyén ismét meglelé, annyira verejtékezett, mintha nagy munkát végezvén, érkezett volna vissza. Ezt nemcsak a többi káptalanbeliekkel, hanem sok szerzetes pappal közölte a kustor" (Pór János minorita krónikatöredéke. p. 162.)

${ }^{59}$ László I. In: Diós István (szerk.): Magyar Katolikus Lexikon. Budapest, Szent István Társulat, 2002. VII. p. 663.

${ }^{60}$ Moser Zoltán: Szent László lándzsájának hegyéről. In: A magyar művelődés és a kereszténység. Budapest-Szeged, Nemzetközi Magyar Filológiai Társaság-Scriptum Rt.,1998. p. 558. Kifejezetten a Szent László és Szent Jakab párhuzamhoz lásd: Holik Flóris: Szent László-mondáink és Compostellai Szent Jakab. Katolikus Szemle, 1923. 7. szám, pp. 65-79.

${ }^{61}$ Sántha György: A harcos szentek bizánci legendái. Budapest, Pázmány Péter Tudományegyetemi Görög Filológiai Intézet. 1943.

${ }^{62}$ Szent Dömötör. In: Diós István (szerk.): Magyar Katolikus Lexikon. Budapest, Szent István Társulat, 1993. II. p. 700.

${ }^{63}$ Kerny Terézia: A katonaszentek ikonográfiájának néhány sajátossága és szerepe a középkori magyar művészetben. Ars Hungarica, 12. évf. (1984). pp. 161-176. 
világrend alapjait adják tovább tér és idő felett, amelybe sem a baloldaliság, sem a liberalizmus eszméi nem férnek bele. A magyar Szent László belép azoknak a „csatában segítő” szenteknek a kultuszába, amelyek Isten népét a jó és rossz princípiumok örök küzdelmében segítik. ${ }^{64} \mathrm{~A}$ konkrét csata, ahol a szent megjelenik ehhez képest másodlagos.

A nagy „kulturális” összekapcsolódás, azonban nemcsak a nagy történetekben figyelhető meg, hanem a Szent László karakterét kiegészítő egyéb motívumaiban is. $A$ jó erők melletti elköteleződés egy sajátos kifejeződése például a testi karakter. ${ }^{65} \mathrm{~A}$ külső és a belső harmóniája a „lovagi szépségben” (pulchritudo) jelenik meg. „Lelki és testi” jó tulajdonságokkal rendelkezett, akiről a korabeli szöveg így ír „erős karú, gyönyörű arcú” vagy „megnyerő szép volt külseje (...).” László testi megjelenésével is alá akarták támasztani, hogy Isten áldása van rajta, és „nemcsak lelkileg, de testileg is királyságra termett”. „Csak szépsége is királyságra méltó; nem elégszik senki reá nézni” - mondja a legenda Lászlóról. A középkori felfogás szerint „a termet, az erő, a barátság, kellemes hang", a korabeli ember a királyról alkotott eszményképe egyben a Biblia világába kalauzol. Különösen is jelentős a „szabályos szép arc”, amely a bibliai Dávid királynál is megjelenik. A „Dávid karakter” egyébként is ideaként szolgált a középkori királyeszme megalkotásához, ${ }^{66}$ amelyet - úgy tűnik - László esetében is felhasználtak. A szépség, a szép arc különösen az ellenségek viszonylatában válik még dominánsabbá, minthogy a csúf és a groteszk arcú individuumok a Sátán, a gonosz erők ${ }^{67}$ földi képviselői. ${ }^{68}$ Bár a szépség hangsúlyozása a legszembetűnőbb, ${ }^{69}$ emellett más párhuzamokat is fellelhetünk: a barátság, ${ }^{70}$ a saját népből származó

\footnotetext{
${ }^{64}$ A segítő szentek kultuszát jól összefoglalja a Magyar Katolikus Lexikon szócikke. A historikus bemutatásánál azonban fontosabb az a mélyebb üzenet, amelyet a "harcban segítő" szentek jelképeznek. Álljon itt egyetlen zsoltár ennek a tradicionális felfogásnak a szemléltetésére „A megpróbáltatás napján hallgasson meg az Úr, védelmezzen meg Jákob Istenének neve! Küldjön neked segítséget szentélyéből és Sionból oltalmazzon téged! (...) Most már tudom: Az Úr győzelmet adott fölkentjének, meghallgatta szent egéből, győzelmes jobbjának erejében. Némelyek a harci szekerekben, mások a lovakban bíznak, mi ellenben Urunk, Istenünk nevét hívjuk segítségül Ők összeestek és a földre rogytak, mi pedig állunk és maradunk. Uram, adj győzelmet a királynak, s hallgass meg bennünket, amely napon hozzád kiáltunk!" Zsolt 20. Lásd még 5 Móz 28 58; Péld 18,10. ${ }^{65}$ Aprólékosan gyüjtötte össze Szent László testi karakterére vonatkozó részleteket: Karácsonyi János: Szent László király élete. Budapest, Szent István Társulat, 1926.

${ }^{66}$ Elka, Bakalova: King David as a Model for the Christian Ruler: Some Visual Sources. In: Biliarsky, Ivan, Paun Radu G. (szerk.): The Biblical Models of Power and Law: Papers of the International Conference, Bucharest. Frankfurt am Main: New Europe College, 2005. 2008. pp. 93-131 Dávid bibliai ábrázolásának kritikájához lásd McKenzie, L. Steven: Dávid király - életrajz. Debrecen, Gold Book, 2000.

${ }^{67}$ Taylor, William: David King of Israel. His Life and its Lessons. New York, Herper, 1875. pp. 41-58.

${ }^{68}$ Jaeger, Stephen: The Origins of Courtliness, Civilizing Trends and the Formation of Courtly Ideals, 939-1210. Philadelphia: University of Pennsylvania Press, 1991. pp. 115., 147-149.

${ }^{69}$ Dávid harcaihoz, győzelmeihez lásd: Dougherty, J. Martin, Haskew E. Michael, Jestice G., Phyllis, Rice S. Rob: Bibliai csaták. Budapest, Ventus Libro Kiadó, 2010. pp. 70-73.

${ }^{70}$ Dávid-Jonatán története párhuzam: László és Ernyei Ispán, akit „a hullák közt járva megismert (...), leugrott lováról, megölelte és így szólt: békesség barátja, úgy sajnállak, mint testvéremet (...)."
} 
ellenség megkülönböztetése a kívülről betörő ellenséggel szemben, ${ }^{71}$ a nagylelkűség, az Istennek tett ígéretek a győzelem esetére stb. ${ }^{72}$

A jó erők és a kereszténység melletti elköteleződés sajátos megnyilvánulása, hogy a legenda szerint a clermont-i zsinatra 1095-ben összegyűltek Szent Lászlót választották a keresztesek fővezérének. Ahogy azonban arra több szerző is rámutat, erre kevés esély volt, mivel a „lovagkirály már négy hónapja meghalt."73 Más források elismerik, hogy a keresztes háború megindulása előtt az országon átvonuló francia, spanyol, illetve angol „zarándokok” fölkérték a királyt, hogy vegye át vezetésüket, László pedig hajlott erre, de a cseh örökösödési háború, illetve a halála meghiúsította a kezdeményezést. Az általunk vizsgált szempontból azonban semmi jelentősége nincs a kérdés történeti hitelességének, hiszen akárhogy is volt, a keresztes hadjárat kapcsán is erősödött a Szent Lászlóhoz kapcsolt idea, mely szerint ő az egyház és a kereszténység védelmezője.

\section{A természetfeletti erők küzdelmének szimbolikus ábrázolása}

Szent László kultikus tisztelete nemcsak a legendáriumokban, hanem a korabeli templomfestészetben is megjelent. ${ }^{74} \mathrm{Az}$ ábrázolások igyekeztek kifejezni László királyi legitimitását: korona, jogar, országalma; és a katonai idoneitását: kard, páncél, köpeny, ${ }^{75}$ kettőskeresztet ábrázoló pajzs (amely sajátos lászlói attribútum); és különösen a bárd (amely valószínűsíthetően csak későbbi, de kifejezi a harcra való állandó készséget és azt a testi erőt, amely a nagyméretű fegyver felemeléséhez szükséges). ${ }^{76}$ A művészeti ábrázolások nemcsak feldolgozzák a László-legendákat, hanem szemléletesen fejezik ki a jó és a rossz princípiumok örök harcát, amelybe a lovagkirályt a jó oldalon szerepelteti. A legkoncentráltabban ezek az ábrázolások Erdélyben és a Felvidéken találhatók. Egyes vélemények szerint ennek mindössze az a magyarázata, hogy a törököktöl meg nem szállt területeken jobban megmaradtak a korai egyházművészeti emlékek. Más megközelítés szerint a Lászlókultusz eleve ezeken a határmenti területeken bontakozott ki a legnagyobb erővel, hiszen az egykori király jelentős katonapolitikai döntései közé tartozott a végvárrendszer megerősítése és a határszakaszok védelme.

\footnotetext{
${ }^{71}$ Dávid megsiratja Sault (Kir 1,16), László gyászolja ellenségét Videt a mogyoródi csata után.

72 Lábán Antal: Dávid. In: Bangha Béla (szerk.): Katolikus Lexikon. Budapest, 1931. I. p. 432.

73 Ráadásul a keresztesek nem is egyetlen vezető alatt indultak a harcba. Tarján M. Tamás 1096. augusztus 15. | Lovagsereg indul a Szentföld felszabadítására. Rubicon. http://www.rubicon.hu/magyar/oldalak/1096 augusztus 15 lovagsereg indul a szentfold felszabadit asara/ (Letöltés ideje: 2018. 07. 20.); Magyar Zoltán: „Keresztény lovagoknak oszlopa”. i. m. p. 27. ${ }^{74}$ Lángi József: Szent László ábrázolásairól. https://eda.eme.ro/bitstream/handle/10598/28680/EME DOLG20112012 LangiJozsef.pdf?sequence=1\&isAllowed=y (Letöltés ideje: 2018. 07. 18.)

${ }^{75}$ Seibert Jutta (szerk.): A keresztény művészet lexikona. Budapest, Corvina, 1986. p. 202.

${ }^{76}$ A királyi és katonai alkalmasság kérdéséhez lásd: Kristó Gyula: Legitimitás és idoneitás. (Adalékok Árpád-kori eszmetörténetünkhöz) Századok, 108. évf. (1974). pp. 585-621.
} 
Sok esetben már azoknak a templomoknak a titulusa is beszédes, ahol a Lászlóról szóló templomfreskók találhatóak. Néhány szemléletes példa: a karaszkói templomot Alexandriai Szent Katalin, a szentmihályfai templomot Szent Mihály arkangyal, ${ }^{77}$ a szepeshelyi ${ }^{78}$ Szent Márton, ${ }^{79}$ a vörösalmai templomot 1714-töl szintén Szent Márton, előtte Antiochiai Szent Margit, majd Szent András ${ }^{80}$ tiszteletére szentelték. Hosszasan lehetne sorolni az egyes templomokat, ahol a Szent László ábrázolások találhatóak. Szinte minden eseteben mintha tudatosan figyeltek volna, hogy olyan védőszentet válasszanak a templomnak, aki a hit igaz harcosa, legyen az akár fizikai harc vagy a pogány állami vezetőkkel, illetve a gonosz erőkkel folytatott hitvita, vagyis szellemi küzdelem. Még olyan esetben is, mint a pónikai templom, amelyet Isten „szegénykéje”, Assisi Szent Ferenc tiszteletére szenteltek, megtaláljuk ezt a kapcsolatot. Ugyanis Celanói Tamás ${ }^{81}$ Szent Ferencröl szóló legendás elbeszéléseiben is számos történetet olvashatunk a gonosz erök és Szent Ferenc harcairól, de elég Giotto (Ambrogiotto di Bondone) freskójára gondolni, aki megfestette azt a történetet, ahogyan Szent Ferenc kiüzi Arezzóból az ördögöket. ${ }^{82}$

Lehetne tovább elemezni a korabeli Szent László-ábrázolások és a templomok titulusai közötti kapcsolatot, illetve bemutatni az egyes védőszentek valós és spirituális küzdelmeit a „gonosszal”. A néhány példa is jól szemlélteti azonban, hogy az említett templomok védőszentjei ugyanannak a nagy harcnak részesei: időn és téren átívelö „fegyvertársak” a gonosz princípiumokkal szemben. Szent László ebbe a természetfeletti harcba kapcsolódik be. Az ábrázolások kapcsán - ahogy arra a legendáknál már utaltunk - szintén feltűnik, hogy László király a gonosz princípiummal folytatott harcban „transzperszonálizálódik”. Ez azt jelenti, hogy hasonló ábrázolásokat más szentek esetében is találunk. Szinte összeolvadnak a jó oldalon - mint ahogy összeolvadnak a rossz oldalon - harcoló személyek. Ez nem a történetek „meghamísítása”, hanem a jó és rossz örök harcának történelmi korszaktól független örökkévalóságát szemlélteti. Az sem elhanyagolható szempont, hogy Szent László ezzel a harccal a legfontosabb szentek, az apostolok, és maga Krisztus fegyvertársa lesz. Jézus a Biblia tanúsága szerint ördögöket üz ki, a tanítványoknak

\footnotetext{
${ }^{77}$ Schütz Antal: Szent Mihály arkangyal. In: Schütz Antal (szerk.): Szentek élete I-IV., Budapest, Szent István Társulat, 1932-1933. Imádságokban: Szent Mihály arkangyal, védelmezz minket a küzdelemben; a sátán gonosz kísértései ellen légy oltalmunk! Esedezve kérjük: „Parancsoljon neki az Isten!" Te pedig, mennyei seregek vezére, a sátánt és a többi gonosz szellemet, akik a lelkek vesztére körüljárnak a világban, Isten erejével taszítsd vissza a kárhozat helyére! Amen. A müvészetben pedig Boucher, Bruce: Saint Michael and the Devil. Journal Article Art Institute of Chicago Museum Studies, 32. évf. (2006), 1. szám, pp. 48-49.; 95.

${ }^{78}$ Átfogó elemzéséhez lásd: Jankovics Marcell - Méry Gábor: A szepeshelyi Szent Mártonszékesegyház. Budapest, Méry Ratio, 2010.

79 Ujházl Lóránd - Kliszek Németh Noémi: A szerzetestöl és a püspöktöl a katonáig, avagy a szent márton kultusz formálódása. Felderítő Szemle, 15. évf. (2016), 4. szám, pp. 32-41.

${ }^{80}$ https://archiv.katolikus.hu/szentek/szent232.html

${ }^{81}$ Celanói Tamás életrajzai Szent Ferencröl. Szent Ferenc Első Életrajza (Vita Prima)/Szent Ferenc Második Életrajza (Vita Secunda)/Szent Ferenc Csodái (Tractatus De Miraculis). Szeged, Agapé, 1993.

${ }^{82}$ A művészet története. A korai reneszánsz. Budapest, Corvina, 1990. p. 27.
} 
adott missziós utasításban pedig lefekteti: „üzzetek ki ördögöket” (Mk 6 6-13). A márki missziós parancsban, ahol Jézus a tanítványok számára alapfeladatként határozza meg a gonosszal szembeni harcot, egy sor tilalmat is felsorol. Jézus számba veszi mindazokat az eszközöket, amelyeket az apostolok a missziós út alkalmával nem vehetnek igénybe: ${ }^{83},(.$.$) és meghagyta nekik, hogy semmit se$ vigyenek az útra egyetlen vándorboton kívül, se kenyeret, se tarisznyát, se pénzt az övükben." (Mk 6 9.) Nem világos, hogy a bot, miért jelent kivételt, hacsak nem nagyobb összefüggésbe helyezzük el a (pásztor)bot jelentését. Az eredeti föpapi pásztorbot - ahogy az egyes keleti egyházakban ma is megfigyelhetö - kígyó - akár két kígyó - formában végződött. A kígyó nemcsak bibliai szimbólum, hanem a szélesebb hagyományban magát a gonoszt szimbolizálja. ${ }^{84} \mathrm{~A}$ bot ebben az összefüggésben már nem az anyagi világhoz tartozik, hanem azt a szellemi és lelki hatalmat jelképezi, amellyel az egyház győz a gonosz erők felett. ${ }^{85}$

Maguk a freskóábrázolások is teológiai jelentőséggel bírnak. Több településen például a kakaslomnici templomban a „leányrabló kun” elbeszélést dolgozták fel, ahol a "harcos lovas alakja, a két férfi fegyvertelen birkózása, és a kun harcos lefejezése" szintén a princípiumok közötti harcra utal. ${ }^{86}$ Stanczik-Starecz Ervin különösen a birkózás jelenetére hívja fel a figyelmet - amely több templom fali képén is megjelenik. A csupasz kézzel történő birkózás „mitikus méretekben zajló, kozmikus párviadal," ${ }^{87}$ amelyet földi fegyverekkel nem lehet megvívni. Ugyancsak a földi eszközök elégtelenségét jelképezi a leányrablás jeleneténél, hogy Szent László lándzsája átdöfi a kun harcos mellkasát, amelynek a szájából tủz vagy füst száll ki (ez a többi képen is visszatér), de a sérülés nem akadályozza meg ellenségét abban, hogy nagy erőt igénylő mozdulattal felhúzza a nyilát. ${ }^{88} \mathrm{Ez}$ a természetfelletti, démoni erőt jelképezi. Az ábrázolások László alakját idealizálják, sőt „alter Christus”-ként mutatják be, hiszen arca Krisztushoz hasonlít. Ez egyben a lelki nagyságot is szimbolizálja, hiszen az alter Christus megközelítést a teológiában elsősorban a papokra alkalmazták, akik az igehirdetésen és a szentségkiszolgáltatáson keresztül Krisztusnak, a fönek személyében járnak el. ${ }^{89}$ László kiválóságát esetenként még azzal is szemléltetik, hogy „kicsit magasabb, lefelé hajtja fejét, arca inkább szomorú

\footnotetext{
${ }^{83}$ Harrington, J. Daniel: Evangélim Márk szerint. In: Thorday Attila (szerk.): Jeromos bibliakommentár II. Az Újszövetség könyveinek magyarázata. Szent Jeromos Katolikus Bibliatársulat, 2003. pp. 62-63.

84 Kígyó: In: Hoppál Mihály - Jankovics Marcell - Nagy András - Szemadám György (szerk.): Jelképtár. Budapest, Helikon Kiadó, 2010. pp. 162-163.

${ }^{85}$ Ez a Szűz Mária ábrázolásokban is gyakori, ahol Mária eltapossa a kígyó az „ősgonosz” fejét.

86 Tornay Krisztina: A Szent László-legenda, mint a szakrális beavatás helye - A felvidéki Szent László-ciklusok (2.) - A Jó és a Rossz harca. http://www.rovart.com/hu/a-szent-laszlo-legenda-mint-aszakralis-beavatas-helye-a-felvideki-szent-laszlo-ciklusok-2 2695 (Letöltés ideje: 2018. 07. 13.)

Stanczik-Starecz Ervin: A Szent László-legenda sámánisztikus elemei: http://www.kutyahon.de/erdelyi.templomok/gelence/samanisztikai.elemek.htm (Letöltés ideje: 2018. 07. 13.)

${ }^{88}$ A visszafelé nyilazó kunban egyesek a pogány magyar szokásokat is látják. Ez jelképezi a múltat, amíg Lászlóban megjelenő keresztény lovagkirály a jelent és a jövőt. Klaniczay Gábor: A Szent-László kultusz kialakulása. i. m. p. 35.

${ }^{89}$ Ratzinger, Joseph: Ministero e vita del sacerdote. Brescia, 2005. p. 165.
} 
és szelíd, mint indulatos." A legtöbb ábrázoláson a szembenálló felek közötti harc természetfeletti jellegét a lovak színével is érzékeltetik (Bögöz, Gelence, Bibarcfalva, Csíkszentmihály, Kakaslomnic, Karaszkó, Gútor stb). ${ }^{90}$ A király világos, a kun harcos sötét lovon ül. Az is előfordul, hogy maguk a lovak is támadják, harapják egymást, dramatizálva az egymással egyetemesen szembenálló princípiumok harcát. ${ }^{91} \mathrm{~A}$ fekete ló a sötétség kánjának lova, amíg a fehér lovat a "győzelmes nappal, a Chrisztosz Koszmokrátosszal azonosították már a IV. században." A már többször idézett Magyar Zoltán külön tanulmányban dolgozta fel a lovakhoz köthető szimbolikus elemeket. ${ }^{92}$ Más helyen a szembenálló felek ruhájának a színével (Székelyderzs, Svábfalva, és Rimabánya fali képein) vagy a kun balkezességével érzékeltetik (Erdőfüle, Sepsibesenyő, Székelydálya, Kakaslomnic, Rimabánya, Bántornya) a jó és a rossz erők szembenállását. ${ }^{93} \mathrm{Az}$ ábrázolásokat László Gyula a keresztény Szent László-legenda korai gyökerü, még a sztyeppei nomád világból eredő mitikus hősmondákkal is kapcsolatba hozza. ${ }^{94} \mathrm{Ez}$ is annak bizonyítéka, hogy az igazi különbség a szellemi erőkben hívő, illetve az azt elutasító társadalmak között áll fenn igazán, és nem a különböző vallások között, amelynek tagjai hisznek a természetfeletti erök létezésében.

Végül érdemes utalni arra az „idilli” állapotra, amely mindössze néhány ciklusban jelenik meg (például a póniki és a szentmihályfai templomban), ahol Szent László a „kuntól” megmentett lány ölébe hajtja fejét. A bárd már a földön hever, háttérben a kun karóba húzott feje. A gonosz és a jó princípiumok közötti küzdelemnek vége, az elveszett paradicsom és béke visszatér. A harc nem tart örökké, a gonosz erök megsemmisülnek. Ez is jelzi, hogy az ábrázolásokkal - László harcaival - sokkal többet akartak szemléltetni, mint a két katona közötti küzdelmet. ${ }^{95}$

\section{Összefoglalás}

A kommunista diktatúrát követő években a ,jogállamiság” intézményeinek védelme a jogalkotásban kitüntetett helyen szerepelt. A vallás és lelkiismereti szabadság alapjogi megfogalmazásán túl gyakorlatorientált rendelkezésekre is szükség volt, amelyek különböző élethelyzetben és intézményekben lehetővé tették a vallás és kultusz szabad gyakorlását. Ebbe a jogalkotási folyamatba illeszkedett a Magyar Honvédség állománya számára a vallás és lelkiismeret szabadság biztosítékait lefektető jogalkotási folyamat. Az 1990. évi. IV. törvény a lelkiismereti- és

\footnotetext{
${ }^{90}$ Magyar Zoltán: Táltosló motívum a Szent László-hagyományban. Ethnográfia, 108. évf. (1997), 1-2. szám, pp. 111-122.

${ }_{91}$ Magyar Zoltán: Táltosló motívum a Szent László-hagyományban. i. m. p. 112.

92 Magyar Zoltán alapján. Magyar Zoltán: Táltosló motívum a Szent László-hagyományban. i. m. pp. $111-122$.

${ }^{93}$ Magyar Zoltán alapján. Magyar Zoltán: Táltosló motívum a Szent László-hagyományban. i. m. p. 112.

${ }_{94}$ László Gyula: A Szent László-legenda falképei. Életünk, 23. évf. (1985), 4. szám, pp. 324-352.

${ }^{95}$ Magyar Zoltán: Szent László a magyar művelödéstörténetben. Korunk (Kolozsvár), 27. évf. (2016), 8. szám, p. 31.
} 
vallásszabadságról kimondja, hogy a katonáknak joguk van a szabad vallásgyakorláshoz, amelyet az intézményen belül a törvény megenged, de csak „egyénileg” (7. §. 1). A törvény még megkülönbözteti a katonák katonai intézményen belüli és azon kívüli vallásgyakorlását. $A z$ intézményen kívül a katonai szolgálatot teljesítő személy egyéni és közösségi vallásgyakorlását semmilyen vonatkozásban nem korlátozza (7. §. 2). Ez jelentős lépésnek számított, hiszen a kommunista diktatúra alatt az állami - különösen a fegyveres szervezetekhez tartozó alkalmazottaktól az „ateista attitűd” volt az elvárt „életfelfogás”. Ezt a kommunizmus éveiben különböző módon ellenőrizték is.

A jogalkotó azonban a rendszerváltás után még meglehetősen szűk keretét engedélyezte a vallásgyakorlásnak, mivel nem biztosította a vallás közösségi megélésének lehetőségét. A vallás azonban sohasem pusztán privát, hanem mindig közösségi dimenziókkal is rendelkezik. A katolikus többségü hadseregeknél pedig régi hagyománya volt a katonaszentek és a fegyvernemi védőszentek kultuszának. Ennek egyszerre volt vallási és kulturális dimenziója, amelynek a határai sokszor elmosódtak. Az 1993. évi LXXIII. törvény a lelkiismereti és vallásszabadságról, valamint az egyházakról szóló 1990. évi IV. törvény módosítása közelített a nemzetközi normákhoz. ${ }^{96}$ Ez megváltoztatta az említett 7 . §. 1-t, és csak annyit mondott, hogy a „katonai szolgálatot teljesítő a vallását - a katonai szervezet működési rendjével és a honvédelmi kötelezettség teljesítésével összhangban szabadon gyakorolhatja." A jogalkotó ezzel megszüntette azt a korlátozást, hogy a katonai szolgálatot teljesítő az intézményben csak egyénileg gyakorolhatná a vallását. ${ }^{97}$ Így lehetett megszervezni az egyes felekezetek intézményes jelenlétét a hadseregben. $^{98} \mathrm{~A}$ Magyar Honvédségben mégsem alakult ki a protokolláris tiszteleten, ${ }^{99}$ elszigetelt zarándoklatokon vagy felületes ismereten túl „Szent László” vagy más fegyvernemi védőszent - kultusza, amely mélyebb tudatformáló hatással rendelkezne. ${ }^{100} \mathrm{~A}$ bemutatott teológia-, filozófia- és eszmetörténeti összefüggések fényében egyértelmü, hogy ez nem is lehet másképp. A második világháború után olyan törés következett be, amely fokozatosan szembeállította a társadalmat a vallási közösségekkel, a természetfeletti erőkbe vetett hittel és a spirituális értékekkel. A

\footnotetext{
${ }^{96}$ Római egyezmény 9. cikkelye (1957. március 25.): „mindenkinek joga van a lelkiismeret- és vallásszabadsághoz (...) mind egyénileg, mind együttesen, mind nyilvánosság elött, mind magánéletben (...)."

${ }^{97}$ Schanda Balázs: Magyar állami egyházjog. Budapest, Szent István Társulat, 2003. p. 153.

98 A tábori lelkészi szolgálat létrehozásáról a kormány 1994. április 20-án kiadott 61/1994 kormányhatározattal rendelkezett. Ezzel nem a katonai ordinariátust hozta létre, mert arra egyedül az Apostoli Szentszék jogosult, hanem kialakította azokat a kereteket, amelyek között a történelmi felekezetek a Honvédség - és a Határörség - intézményeiben lelkipásztori munkát végezhetnek. Az egyházjogi dimenziókhoz lásd Ujházi Lóránd: A katolikus katonai ordinariátus struktúrája és szabályozása. Budapest, Szent István Társulat, 2014.

99 Szent László nevét vette fel Ludovika Kápolnája. http://www.magyarkurir.hu/hirek/szent-laszlonevet-vette-fel-ludovika-kapolnaja (Letöltés ideje: 2018. 07. 19.)

${ }_{100}$ Székesfehérvár - Szent Lászlóra, a lovagkirályra, a lövészek védőszentjére emlékeztek szerdán. https://honvedelem.hu/cikk/32465/miert-eppen-szent-laszlo (Letöltés ideje: 2018. 07. 19.)
} 
rendszerváltás után a liberális eszmék ezt a „vallásszkeptikus” magatartást tovább erősítették.

A liberális jogalkotás a maximumát adta, amikor lehetővé tette a kultuszszabadság haderöben való megélését. Ezt azonban komoly tartalommal a végrehajtás már nem képes megtölteni. Ehhez ugyanis szemléletbeli fordulatra lenne szükség, amely a baloldali és a liberális gondolkodástól idegen.

\section{FELHASZNÁLT IRODALOM}

Atkins, Margaret, Dodaro, Robert: Augustine Political Writings. Cambridge, University Press, 2004.

Szent László hadosztály. In: Diós István (szerk.): Magyar Katolikus Lexikon. Budapest, Szent István Társulat, 2007. XII.

Babcock, S. William: Angels. In: Everett Ferguson (szerk.): Encyclopedia of Early Christianity. New York-London, Garland Publishing, 1998.

Bánlaky József: Horvátország meghódítása 1091-ben. In: Uő (szerk.): A Magyar nemzet hadtörténelme. Digitális kiadás: Arcanum Adatbázis Kft., 2001. http://mek.oszk.hu/09400/09477/html/0004/199.html

Bauckham, Richard: Revelation. In: Barton, John, Muddiman, John (szerk.): The Oxford Bible Commentary. Oxford, University Press, 2001. pp. 1287-1316.

Boucher, Bruce: Saint Michael and the Devil. Journal Article Art Institute of Chicago Museum Studies, 32. évf. (2006), 1. szám, pp. 48-95.

Dougherty, J. Martin, Haskew E. Michael, Jestice G., Phyllis, Rice S. Rob: Bibliai csaták. Budapest, Ventus Libro Kiadó, 2010.

Bollók János: Szent László korának magyar értelmisége. Vigilia, 65. évf. (2000), 11. szám, pp. 841-849.

Celanói Tamás életrajzai Szent Ferencröl. Szent Ferenc Első Életrajza (Vita

Prima)/Szent Ferenc Második Életrajza (Vita Secunda)/Szent Ferenc Csodái

(Tractatus De Miraculis). Szeged, Agapé, 1993.

Harai Dénes: Az archaikus népi gondolkodás. Kaposvár, Kató Zsolt, 2016.

Hartman, F. Louis - Lella, A. Alexander: Daniel. In: Brown, E. Raymond, Fitzmayer, A. Joshep, Murphy E. Roland (szerk.): The New Jerome Biblical Commentary. New Jersy, Burns and Oates, 1990. pp. 406-420.

Horváth Cyrill: Szent László-legendáink eredetéről. Budapest, 1928.

Holik Flóris: Szent László-mondáink és Compostellai Szent Jakab. Katolikus Szemle, 1923. 7. szám, pp. 65-79.

Hoppál Mihály - Jankovics Marcell - Nagy András - Szemadám György (szerk.): Jelképtár. Budapest, Helikon Kiadó, 2010. 
Guoth Kálmán: Eszmény és valóság Árpád-kori királylegendáinkban. Erdélyi Tudományos Füzetek, 187. Kolozsvár. 1944.

Györffy György: Szent László. In: Kurucz Ágnes (Szerk.): László király emlékezete. Budapest, Magyar Helikon, 1977.

Epistolae pontificum romanorum genuinae. In: Andreas, Theil: Brunsbergae: Peter Signatur. 1868.

Ignácz Rózsa: Ünnepi férfiú. Budapest, Fapadoskönyvek. 1989.

Jankovics Marcell - Méry Gábor: A szepeshelyi Szent Márton-székesegyház. Budapest, Méry Ratio, 2010.

János István: „Légy a hazádnak bajnoka." Szent László alakja a magyar irodalomban. Szabolcs-Szatmár-Beregi Szemle, 27. évf. (1992), 2. szám, pp. 137-148.

Jaeger, Stephen: The Origins of Courtliness, Civilizing Trends and the Formation of Courtly Ideals, 939-1210. Philadelphia, University of Pennsylvania Press, 1991.

Karácson Imre: Szent László Király Élete. A Győri Szent-László-Társulat Megbizásából. A Szent Király Halálának Nyolczszázados Évfordulójára. Győr, Györegyházmegye Könyvnyomdája, 1895.

Karácsonyi János: Szent László király élete. Budapest, Szent István Társulat, 1926.

Kerny Terézia: A katonaszentek ikonográfiájának néhány sajátossága és szerepe a középkori magyar művészetben. Ars Hungarica, 12. évf. (1984). pp. 161-176.

Klaniczay Gábor: A Szent-László kultusz kialakulása. In. Uő (szerk): Nagyvárad és Bihar a korai középkorban. Nagyvárad, Varadinum Kulturális Alapítvány, 2014. pp. 7-39.

Koszta László: Válság és megerősödés: Pogánylázadások és konszolidáció (10381196). Budapest, Kossuth Kiadó, 2004.

Lábán Antal: Dávid. In: Bangha Béla (szerk.): Katolikus Lexikon. Budapest, 1931. I. p. 432.

Lángi József: Szent László ábrázolásairól.

https://eda.eme.ro/bitstream/handle/10598/28680/EME DOLG2011-

2012 LangiJozsef.pdf? sequence $=1$ \&isAllowed $=y$

László Gyula: A Szent László-legenda falképei. Életünk, 23. évf. (1985), 4. szám, pp. 324-352.

Lengyel Dénes: Régi magyar mondák. Budapest, Móra Ferenc Könyvkiadó, 1972.

Madas Edit: A magyar „szent királyok” közép-európia kultusza liturgikus és hagiográfiai tisztelete a források tükrében. http://real.mtak.hu/9736/1/AH 201312 Madas Edit.pdf

Madas Edit - Horváth Zoltán György: Középkori prédikációk és falképek Szent László királyról. San Ladislao d'Ungheria nella predicazione e nei dipinti murali. Budapest, Romanika Kiadó, 2008. 
Magyar Zoltán: „Keresztény lovagoknak oszlopa”. Nemzeti Tankönyvkiadó: Budapest. 1996.

Magyar Zoltán alapján. Magyar Zoltán alapján. Magyar Zoltán: Táltosló motívum a Szent László-hagyományban. Ethnográfia, 108. évf. (1997), 1-2. szám, pp. 111122.

Magyar Zoltán: Szent László a magyar néphagyományban. Budapest, Osiris, 1998.

Magyar Zoltán: Szent László a magyar művelödéstörténetben. Korunk, 2016. 8. szám, pp. 30-37.

Makk Ferenc: Megjegyzések a Szent László korabeli magyar-bizánci kapcsolatok történetéhez. Acta Universitatis Szegediensis Sectio Historica (1957-1959), 96. évf. (1992). pp. 13-24.

Martin, Kornél, Ugron, István: Fejezetek a Szent László hadosztály történetéböl. Hadtörténelmi Közlemények, 109. évf. (1996), 4. szám, pp. 56-132.

Mándi Tibor - Körösényi András: A magyar politikai rendszer egy negyedszázad után. Budapest, Osiris, 2015.

McKenzie, L. Steven: Dávid király - életrajz. Debrecen, Gold Book, 2000.

Moser Zoltán: Szent László lándzsájának hegyéről. In: A magyar művelődés és a kereszténység. Budapest-Szeged, Nemzetközi Magyar Filológiai TársaságScriptum Rt., 1998.

Nemeskürty István: Mi magyarok. Budapest, Dovin Művészeti Kiadó kft., 1989.

Puskely Mária Claudia: Magyar szentek: Szent István, Szent Imre, Szent Gellért, Szent László, Szent Erzsébet, Szent Margit. In: Magyar kereszténység ezer éve. Budapest, MKPK, 2001.

Ratzinger, Joseph: Ministero e vita del sacerdote. Brescia, 2005.

Rózsa Huba: Az ószövetség keletkezése. Budapest, Szent István Társulat, 1986.

Sántha György: A harcos szentek bizánci legendái. Budapest, Pázmány Péter Tudományegyetemi Görög Filológiai Intézet, 1943.

Sárkány Beáta: Szent László előtt tisztelegtek a katonák. https://honvedelem.hu/cikk/57946 szent laszlo elott tisztelegtek a katonak

Schanda Balázs: Magyar állami egyházjog. Budapest, Szent István Társulat, 2003.

Schütz Antal: Szent Mihály arkangyal. In: Schütz Antal (szerk.): Szentek élete I-IV. Budapest, 1932-1933.

Seibert Jutta (szerk.): A keresztény művészet lexikona. Budapest, Corvina, 1986.

Stanczik-Starecz Ervin: A Szent László-legenda sámánisztikus elemei: http://www.kutyahon.de/erdelyi.templomok/gelence/samanisztikai.elemek.htm

Sz. Jónás llona (szerk.): Középkori egyetemes történeti szöveggyűjtemény. Budapest, Osiris, 1999.

Szovák Kornél: Potestas papae potestas regia. Politikai viták a 14. század elején. Vigília, 64. évf. (1999), 2. szám, pp. 93-99. 
Szmodis Jenő: Dante és kora. A reneszánsz kritikai szelleme. In. Államelmélet. Kézirat. pp. 59-63.

Tarján M Tamás: 1077. január 28. | Véget ér Henrik császár Canossa-járása. Rubicon.

http://www.rubicon.hu/magyar/oldalak/1077 januar 28 veget er henrik csasza $r$ canossa jarasa/

Tarján M. Tamás 1096. augusztus 15. | Lovagsereg indul a Szentföld felszabadítására. In. Rubicon. http://www.rubicon.hu/magyar/oldalak/1096 augusztus 15 lovagsereg indul a szentfold felszabaditasaral

Tattay Szilárd: Regnum és sacerdotium. In: Takács Péter (szerk.): Államelmét. A modern állam elméletének előzményei és történeti alapvonalai. Budapest, Szent István Társulat, 2009.

Taylor, William: David King of Israel. His Life and its Lessons. New York, Herper, 1875.

Thomas, Charles, Léon-Dufour Xavier: Puszta. In: Léon-Dufour Xavier (szerk.): Biblikus teológiai szótár. Budapest:, Szent István Társulat, 1972. p. 1124.

Thuróczy János: A Magyarok Krónikája. Augsburg. 1486. (Ford. Horváth János.) Budapest, 1918. p. 187. http://nemzeti.net/contents/library/01-MAGYARKR.pdf

Tornay Krisztina: A Szent László-legenda, mint a szakrális beavatás helye - A felvidéki Szent László-ciklusok (2.) - A Jó és a Rossz harca. http://www.rovart.com/hu/a-szent-laszlo-legenda-mint-a-szakralis-beavatashelye-a-felvideki-szent-laszlo-ciklusok-2 2695

Török József: Magyar szentek földjén. Budapest, Tulipán, 1999.

Ujházi Lóránd: A csoda szerepe és jogi bizonyítása a boldoggá és a szentté avatási eljárásokban. In: Nagypál Szabolcs, Bányai Ferenc, Bakos Gergely (szerk.). A vallási tapasztalat megértése: Jog, bölcselet, teológia. Budapest; Pannonhalma, L'Harmattan Kiadó; Békés Gellért Ökumenikus Intézet, 2010. pp. 169-198.

Ujházi Lóránd: A katolikus katonai ordinariátus struktúrája és szabályozása. Budapest, Szent István Társulat, 2014.

Ujházi Lóránd - Kliszek Németh Noémi: A szerzetestöl és a püspöktöl a katonáig, avagy a szent márton kultusz formálódása. Felderítő Szemle, 15. évf. (2016), 4. szám, pp. 32-41.

Váczy Péter: Az angyal hozta korona. Életünk, 19. évf. (1982), 1-2. szám, pp. 456466.

Veszprémy László - Szabó Péter: Szent László a gyalogság védőszentje. Budapest, Magyar Honvédség, Oktatási és Kulturális Anyagellátó Központ, 1993.

Veszprémy László: Magyar király a Szentföldön: II. András keresztes hadjárata, 1217-1218. Figyelő, 31. évf. (2009), 4. szám, pp. 3-9. 
Weisbender, Joseph: Szentek élete. Budapest, Szent István Társulat, 1984.

Emlékek a Szent László Társulatról.

http://www.szentlaszlorend.hu/hu/rendi kronika/szent laszo tarsulat

Salamon bukása. I. Géza király. https://www.arcanum.hu/hu/onlinekiadvanyok/MagyarNemzetTortenete-a-magyar-nemzet-tortenete-9A23/szilagyisandor-a-magyar-nemzet-tortenete-21F2/magyarorszag-tortenete-az-arpadokkoraban-10381301-2B1F/elso-konyv-kuzdelem-a-nemzeti-fuggetlensegert2B32/v-fejezet-salamon-bukasa-i-geza-kiraly-2C42/

László I. In: Diós István (szerk.): Magyar Katolikus Lexikon. Budapest, Szent István Társulat, 2002 VII. p. 663.

Szent Dömötör. In: Diós István (szerk.): Magyar Katolikus Lexikon. Budapest, Szent István Társulat, 1993. II. p. 700.

Szent László nevét vette fel Ludovika Kápolnaja.

http://www.magyarkurir.hu/hirek/szent-laszlo-nevet-vette-fel-ludovika-kapolnaja

https://honvedelem.hu/galeria/szent laszlo katonai zarandoklat somogyvaron 